\title{
パラプレジアにおける膀胱上皮化生について
}

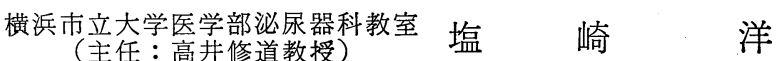

\section{STUDIES ON METAPLASIA OF THE BLADDER EPITHELIUM IN \\ PARAPLEGIA}

\author{
Hiroshi Shiozaki \\ Department of Urology, Yokohama City University, School of Medicine \\ (Director: Prof. Syudo Takai)
}

The normal transitional epithelium of the urinary bladder is histopathologically situated between the squamous cell with lower differentiation and the columnar cell with higher differentiation. In relation to this notion, the author has attempted to raise the following hypothesis.

The epithelium of the bladder, under long-term stess such as chronic infection and physical or chemical stimuli, tends to cause metaplasia in the process of regeneration of injured epithelial tissue, for a better protection of the original epithelium, depending on its environmental situation. The direction of this metaplasia could be towards either squamous or columnar, and these two directions could also be present independently or together in combination. And it would be the bladder epithelium itself that determined the direction of metaplasia, in order to be protected better in each situation. The epithelium, in which metaplasia has once developed, has already started to proceed into the progressive cell-division towards abnormal direction, with a possibility either of continuing its stable activity of metaplasia or growing into a critical condition such as malignant alteration.

Bearing this hypothesis in mind, the author carried out histopathological studies of the bladder epithelium in 154 cases of paraplegia, with use of the specimens such as the cytologic smears of the urine and the tissues of the bladder neck obtained at biopsy and autopsy.

The significant findings in these studies were summarized in the followings.

1) In the smeras of the urine, developement of metaplasia with squamous epithelium was found in 85 cases $(64 \%)$ among 134 cases examined.

2) In the biopsied specimens from the bladder-neck, squamous metaplasia was also found in 25 cases $(73.5 \%)$ among 34 cases.

3) The finding described in 1) and 2) were considered not to be related with the severity of the urinary-tract infection accompanied.

The developent of squamous metaplasia was estimated to be about 5-6 months after the onset of paraplegia when urinary tract infection was accompanied.

4) In the postmortem examination of the urinary bladder in 21 cases of paraplegia, 6 cases had squamous metaplasia, 1 case had partially columnar metaplasia, and 4 cases had bladder carcinoma in which squamous cell carcinoma was found in 3 cases.

The finding that squamous cell carcinoma developed predominantly in the bladder in cases of paraplegsia is considered to be in contrast to the fact that occurrence of adenocarcinoma was observed predominantly in cases of bladder exstrophy, similarly accompanied with chronic infection, being exposed to physical or chemical stimuli for a long period.

It is thus conceivable that the bladder epithelium in cases of paraplegia, under chronic stimuli of infection, has, in its process of regeneration, some difficulty to proceed into its original transitional epithelium, and rather tends to regenerate into squamous cell metaplasia for a protecting effect, and finally to progress into malignancy as squamous cell carcinoma when some unknown cancer-produ- 
cing factors are additionally involved in these situations.

It is also suggested that long-lasting stimuli such as chronic urinary-tract infection and foreign bodies are playing very important roles in cases of paraplegia, in the process of regenerative changes of the injured normal bladder epithelium into squamous metaplasia, and even further into neoplasm.

\section{緒 言}

膀胱に永く慢性感染が存在したり，異物や結石が介在 すると, 膀胱の正常な移行上皮に metaplasia が起る現 象や，更に時にはこのような膀脱化生上皮からneoplasm が発生し易いことは，古くから知られている事実であ る.膀胼上皮化生と慢性刺激との関係については，過去 に多数の議論があり，膀胼に慢性感染を伴う場合につい ては, Striling et al $(1941)^{45}$ Pund et al $(1952)^{32}$ Smith $(1965)^{44)}$ 等が，膀胱に異物が介在する場合については， Goebel $(1905)^{14)}$ Dimmette $(1958)^{8)}$ 等が, 又, 膀脱内 異物実験については,过等 $(1951)^{47)}$ Roe et al $(1964)^{35)}$ 等の報告があり，これらの膀胱上皮が慢性刺激を長期間 受けていると，膀脱上皮に化生が生じ易く，それによつ て生じた膀胱化生上皮は，potential malignant で，癌前 駆症と見なすべきと説く人が多(1)4)779) 10112)15)17719) 22) 23)

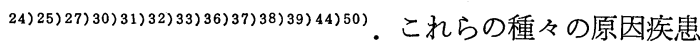
による慢性刺激は 細菌感染によつて生ずる種々な化学 物質による化学的刺激によるものもあり，異物や結石， 或いは，膀脂外反症の場合の様に，衣類，外界との接触 からくる物理的刺激によるものなどが考兄られる．膀脂 の正常移行上皮は，分化度の低い squamous cell と分化

表 1

\begin{tabular}{lll}
\hline Squamous & Transitional Cell \\
Metaplasia & Epithelium
\end{tabular} $\begin{aligned} & \text { Columnar } \\
& \text { Metaplasia }\end{aligned}$

度の高い columnar cell との中間に位し，上述した刺激 を永く受け続けると，膀胱上皮は異常な再生を繰り返す ことになり その上皮再生過程に於いて，生ずる metaplasia は，いずれの方向をも取り得る可能性を有してい ることは，興味深いことである．即ち，分化度の低い方 向をとつた場合は squamous metaplasia となり, 逆に 分化度の高い方向をとつた場合は columnar metaplasia と云われるものになる（表 1).

この様な metaplasia を起した上皮は，既に異常な方 向性を持つてその細胞分裂の第一歩を踏み出して和り，
そのままの化生方向を維続する場合もあれば，更に異質 の因子が加わることによつて, 癌性変化といら重大な病 態に発展してゆく可能性をも有している, paraplegia, tetraplegia の患者は, 周知の如く, cord bladder 飞属 する膀胼機能不全を生涯持ち続け, 急性期には治瘾困難 な尿路感染に罹患する率が極めて高いの及ならず，症状 の安定した慢性期に扣いても，無症候性の膿尿，細菌尿 を有するものが大部分である，即ち 本疾患の患者は永 久的尿路感染を有するか，又は尿路に和梳る菌の永久的 保菌者であるかいずれかに属するといらべきである．更 飞長期間留置カテーテルを置かれたり，或期間膀胼結石 が介在したりすることによる物理的刺激の機会も多い。 これら極めて特殊な異常環境に置かれた paraplegia の 膀胱上皮が，その再生過程に於いて，前述した様な諸変 化を起し得ることは容易に考兄らることである。

近年, 泌尿器科的諸治療の進歩と共に, paraplegia の 患者の腎不全による死亡率が低下し，その平均寿命が次 第に伸びつつある傾向にある反面，欧米に掓る Spinal Center で, paraplegia 患者の膀脱癌の発生率が異常に 高いこと，そしてその原因として，慢性尿路感染が一つ の重要な因子であると云う論文が相次で発表された。即 ち, Melzak (1966) ${ }^{26)}$ の英国 Stoke Mandeville Hospital の統計と, Nysquist, Bors (1967) ${ }^{29)}$ の米国 Veterans Administration Hospital 飞拈けるそれである。著者は国立 箱根療養所で多数の慢性期の paraplegia 患者の治療観 察に当て来たが，その死亡例の中に，剖検時に可成り高 頻度に膀胱癌が証明されること, 又との生存中の診断が 可成り困難であること，換言すれば，非定型的な膀胱癌 発育の形をとるものが多いことに注目していた時でもあ り，本邦に捺ける慢性期の paraplegia 患者についても， 同様な問題点が存在することが予想されるに至つた。そ こで, 本邦の paraplegia 患者にも果して膀胼癌発生率が 正常人に淤をるそれよりも高いのか，又，組織学的に欧 米の報告の如く, 異所性の像を示するのが多いか否か， 又, これらの現象の基盤になるものは何かといら問題に 関していささか検索を試み若干の知見を得た。 


\section{研究対象ならびに研究方法}

I . 研究対象

イ. 剖検による膀胼組織

昭和 24 年 4 月から昭和 43 年 8 月までに国立箱根療養所 にて死亡した paraplegia 48名の中で膀胱組織が得られ た21例についてその組織像を再検討した。

口. TUR による膀脱生検組織

国立箱根療養所に入所中の paraplegia で，排尿障害 を有する最低 4 カ月, 最高28年 3 カ月経過 した患者に TUR を施行し, その時得られた膀胱䅡部組織34例に病 理組織学的検索を加えた.

\section{八. 膀胱尿細胞診}

昭和42年 1 月から昭和 43 年 8 月までに国立箱根療養所 で加療を受けた最低 4 カ月から最高30年 6 カ月経過した paraplegia 134名に膀脱粘膜上皮の細胞診を行ない，そ の病理学的 pattern を追求した.

2. 研究方法

1. 剖検例による膀羘上皮組織

H.E. 染色による得られた膀胱組織標本につき顕微鏡 そて, 膀脱上皮の炎症の程度, metaplasia の有無, その 程度, neoplasm の有無の検索を行なつた。これらの判 定は次の基準に従つた。炎症：炎症性細胞浸潤が著明 なものを(H), 炎症性細胞浸潤が比較的軽度なるのを (十), 炎症性細胞浸潤を認めないるのを（一）とした。 metaplasia-squamous metaplasia: 扁平上皮細胞の出現が 著明で全上皮細胞数の半数以上を占めるものを(\#),一 部扁平上皮細胞の出現を認めるものを $(+)$, 扁平上皮細 胞の出現を認めないものを（一）とした. Brunn's nest: 組織中に著明にBrunn の細胞巣を認めるものを(\#), 軽 度に認めるものを（十，認めないるのを（一）とした。 口. TUR による膀脂生検組織

TUR にて膀胱䅡部組織（ 3 時～9時）を切除し，除 し, 10\%ホルマリンにて固定, 標本は H.E 染色にて, 顕鏡で剖検例と同様の検索を行なつた。 その判定基準 も剖検例のそれに従つた. 又, TUR 施行前の尿一般検 査, 残尿の判定は次の基準に従つた。尿一般検査は, 蛋白 : ズルホサルチル酸法で白濁を軽度認めるるのを (十), 中度以上認めるものを (H), 白血球, 細菌 : 顕鏡 $(40 \times 10)$ にて, 各視野に $5 \sim 6$ 個以上20個位までのも のを(十),それ以上のものを（\#）とした. 又，残尿は $50 \mathrm{ml}$ 以上 $100 \mathrm{ml}$ 位までを $(+), 100 \mathrm{ml}$ 以上のものを (\#),とした。

八. 膀胱尿細胞診
できるだけ新鮮で, かつ変形や変質のない膀脂上皮細 胞を採取するために，生理的食塩水を膀脱に注入し，パ ンピング操作を行ないがら膀胱を洗滥する方法を用い た. Paraplegia 患者の膀脱は，常時その大部分が膿尿に 近い尿を排尿しているので, 被験者の膀胱にカテーテ ルを挿入して生理的食塩水 $50 \sim 100 \mathrm{ml}$ を膀脱内に注入 して $5 \sim 6$ 回軽くパンピングを行ない，この液は全部捨 てた．同様の操作を 3 回行ない，最後の 3 回目の液を用 いて検査材料とし，この操作を行ならことによつて，で きるだけ原形を保つた新鮮な膀胱上皮細胞が採取でき， その形態的特徵をできるだけ明確にし，又，膀胱以外の 細胞が検体に含まれないようにするのが目的である．こ のようにして膀胱洗滌した液を直ちに遠心沈澱管に分注 し，3000rpm で 5 分間の遠心沈澱を行なう．沈椬を駒込 ピペットで吸引し，よく脱脂した卵白グリセリンを塗つ た載物ガラスに滴下する．滴下した沈椬は適当な厚さに のばし，沈渣が完全に乾固しないらちに，エタノール： エーテル等量混合液飞浸潤固定した. いわゆる wet smear technique 亿属する操作である.固定は30分間を原則とし た。標本は 1 検体につき 2 枚作製し，染色は米国Warter Reed 陸軍病院法で Papanicolaou 染色をした.この検 查は各被験者に $5 \sim 6$ カ月毎に $2 \sim 3$ 回行なつた. 各 標本の各上皮細胞，悪性細胞の検索を行なつた。その 判定は次の基準に従つた. 顕鏡 $(40 \times 10)$ にて, 各視野 に transitional cell を $2 \sim 3$ 個認めるものを $(+)$,それ 以上認めるものを (H), parabasal cell (n/c が $1: 1$ 〜 1:3，原形質が basophilic に染まるもの）を各視野 飞2〜3 個認めるものを $(+)$,それ以上認めるものを (H), intermediate cell (n/cが $1: 3 \sim 1: 8$, 原形質 が basophilic でうすく染まるもの）を各視野に 2 ～個 認めるものを (十)，それ以上認めるものを(\#), cornified cell (n/c が 1：8〜1：20位で細胞の形態が敷石 状で原形質が orange 色に染をり，核が pyknotic のも の）を各視野に $2 \sim 3$ 個認めるものを（十），それ以上 認めるものを（）とした，又炎症性細胞を各視野に $5 \sim 6$ 個認めるものを $(+), 10 \sim 15 ， 6$ 個認めるるのを (\#), それ以上多数認めるものを（州）とした。，又，標 本中に悪性細胞（核の膨大，染色質の増量，粗大顆粒 の出現, 核 : 細胞質の増加, 核縁の不規則性等) を認 めるものを $(+)$ とした. 同一検体に parabasal cell, intermediate cell, cornified cell と各層の細胞, 又は, intermediate cell, cornified cell を認める場合にはその 被験者の膀胱上皮には squamous metaplasia が生じてい 
ると判定した。

\section{研究成績}

\section{1. 剖検による膀胱組織所見}

昭和 24 年 4 月から昭和 43 年 8 月までに国立箱根療養所 に於いて加療を受けた 267名の中で48名が死亡した。そ の全例に剖検を施行しているが（表 2),48名中膀胱組織 が得られた21名の膀脂組織を顕鏡にて検索した結果（表 3）の如く, 膀脱上皮に squamous metaplasia を認めた ものは 6 名, Brunn の細胞巣を認めたものは 6 名, 両者 を共に有するものは 2 名である. columnar metaplasia を部分的に認めたものは 1 名であつた. 又, 膀脂癌は 4 名で, squamous cell carcinoma-3, transitional cell carcinoma-1 であつた，その年令は，47才，48才，47才， 50才と比較的若く, paraplegia 発症後の期間は, 19年11 カ月〜26年10カ月であつた. 残り 7 名の膀胱組織は膀 脱上皮が脱落して上皮所見の不明なもの 5 名, 他の 2 名 は得られた膀胼標本からは炎症所見以外に特に異常を認 めなかつた，以上の成績結果から膀胱上皮に異常を認め
表 2 死亡直接原因

\begin{tabular}{|c|c|c|c|}
\hline 原 & 因 & 例数 & 割 合 \\
\hline \multicolumn{2}{|c|}{ 腎 不 全 } & 28 & $57.4 \%$ \\
\hline \multirow{2}{*}{ 悪性腫瘍 } & 膀胱癌 & 4 & $8.3 \%$ \\
\hline & 褯㾒癌 & 3 & $6.4 \%$ \\
\hline \multicolumn{2}{|c|}{ 肺 炎 } & 3 & $6.4 \%$ \\
\hline \multicolumn{2}{|c|}{ 肺 結 核 } & 2 & $4.2 \%$ \\
\hline \multicolumn{2}{|c|}{ 腸 閉 塞 } & 2 & $4.2 \%$ \\
\hline \multicolumn{2}{|c|}{ 脳 出 血 } & 2 & $4.2 \%$ \\
\hline \multicolumn{2}{|c|}{ 裖 癜感染 } & 1 & $2.1 \%$ \\
\hline \multicolumn{2}{|c|}{ 精神分裂病 } & 1 & "I \\
\hline \multicolumn{2}{|c|}{ 全麻時ショック } & 1 & " \\
\hline \multicolumn{2}{|c|}{ 自 殺 } & 1 & " \\
\hline \multicolumn{2}{|l|}{ 計 } & 48 & \\
\hline
\end{tabular}

たものは21名中14名 $(66.6 \%)$ で そのうち4名が膀胼 癌である。

Paraplegia の膀脱癌の診断を生前につけるのは nonparaplegia の比して非常に困難である場合が多い，そ

表 3 剖検例の膀胱組織所見

\begin{tabular}{|c|c|c|c|c|c|c|}
\hline \multirow[b]{2}{*}{ 症例 } & \multirow{2}{*}{\multicolumn{2}{|c|}{ 年令 性 }} & \multirow[b]{2}{*}{ 期＼cjkstart間 } & \multirow[b]{2}{*}{ 炎症 } & Metaplasia & \multirow[b]{2}{*}{ 参 } \\
\hline & & & & & \begin{tabular}{c|c} 
Sq. Met. & $\begin{array}{c}\text { Brunn's } \\
\text { nest }\end{array}$
\end{tabular} & \\
\hline 1 & 69 & $\hat{0}$ & 2 力月 & + & 上 皮 脱 落 & 留. カテ. 2 カ月 \\
\hline 2 & 52 & 우 & 7 月月 & + & $+\quad+$ & 留. カテ. 6 カ月 \\
\hline 3 & 46 & $\hat{0}$ & 5 年 3 力月 & $H$ & $-1+$ & 留. カテ. 2 年 8 カ月 \\
\hline 4 & 30 & $\delta$ & 5 年11カ月 & + & 上 皮 脱 落 & 留. カテ. 2 年 5 カ月 \\
\hline 5 & 49 & $\hat{\delta}$ & 8 年 8 力月 & + & $-1+$ & 留. カテ. 2 年間 \\
\hline 6 & 38 & 令 & 11 年 5 力月 & + & 上 皮 脱 落 & \\
\hline 7 & 30 & $\hat{0}$ & 12 年 2 力月 & + & $-1+$ & 留. カテ. 4 年間* \\
\hline 8 & 47 & $\hat{\delta}$ & 12年 6 力月 & + & + & 留. カテ. 2 年間 \\
\hline 9 & 42 & 今 & 13 年 2 力月 & + & + & 留. カテ. 11 月 \\
\hline 10 & 49 & $\hat{0}$ & 15年 7 カ月 & + & - & 留. カテ. 2 年間 \\
\hline 11 & 60 & 全 & 14年 8 力 & + & + & 留. カテ. 4 年 6 カ月 \\
\hline 12 & 43 & $\hat{\delta}$ & 17年 2 力月 & + & - & 留. カテ. 5 年 7 カ月 \\
\hline 13 & 47 & $\hat{0}$ & 18年 6 力月 & + & $-1+$ & \\
\hline 14 & 47 & 全 & 19年11カ月 & & Transitional cell ca. & 膀胱結石あり \\
\hline 15 & 48 & $\hat{0}$ & 20 年 2 力月 & $H$ & 上 皮 脱 落 & \\
\hline 16 & 49 & $\hat{0}$ & 24年 8 力月 & + & $+1-$ & 留. カテ. 3 年間 \\
\hline 17 & 60 & $\hat{0}$ & 25 年 3 力月 & $H$ & 上 皮 脱 落 & \\
\hline 18 & 48 & $\hat{O}$ & 25 年 4 力月 & + & $+1-$ & 留. カテ. 7 年間 \\
\hline 19 & 48 & $\hat{0}$ & 25 年 7 カ月 & & Squamous cell ca. & 留. カテ. 6 年間. 膀胱結石 \\
\hline 20 & 47 & $\hat{O}$ & 26 年 6 力月 & & Squamous cell ca. & 膀胱結石あり \\
\hline 21 & 50 & $\hat{0}$ & 26年10力月 & & Squamous cell ce. & 膀胱結石あり \\
\hline
\end{tabular}

* 一部にColumnar metaplasia を認めた

Sq. Met.=squamous metaplasia. 留. カテ.=留置カテーテル 
の理由は paraplegia の膀胱は常時血膿尿を伴つていね り，時には結石の為に血尿が増強していることもあり， non-paraplegia の膀朕癌と典型的な症状とは大いに異な る場合が多い，又，膀脂自体に変形をきたし，レ線撮影 でも non-paraplegia の様に陰影欠損として現われにく く，膀胱鏡検査もその施行が困難な場合や，炎症や，肉 柱形成が強度で膀胱腫瘍との判別が困難であつたり，た とえ腫瘍があつても，表面は壊死物質に被われて肉眼的 には識別不能なことが多い.4名の膀脱癌も生前に診断 がついたのは症例20のみであつた。

症例14. 剖検時 47 才, 昭和14年 4 月 7 日戦地にて受傷 （当時27才）,腰部銃弾破片創兼脊䯣損傷を発症する. 昭 和24年 1 月頃から血膿尿の排尿が生じ，同年 2 月に，大 豆大の結石 2 個が排出されているとの後血膿尿は改善さ れた. 昭和 35 年 9 月頃から再び血膿尿が増強し，下腹部 に小児手掌大の腫瘤を触れる様になつて来た。この腫瘤 はその後特に増大なく，悪液質状態にて昭和 36 年 2 月 12 日死亡した. 剖検時, 膀胱所見は膀胱壁全体が肥厚し 一部乳頭状を呈する所もあるが腫瘍組織で占められてい る. 病理組織学的には, transitional cell carcinoma で あつた。

症例19. 剖検時48才, 昭和14年 4 月 20 日（当時34才） 煉瓦壁倒壊しその下敷さとなり 第 11,12 胸椎骨折兼脊 髄損傷を発症する. 昭和 24 年 2 月頃からしばしば発熱を 伴い, 血膿尿を排尿し 両腎部の疼痛を訴え, 留置カテ 一テルを昭和 32 年 6 月まで置かれている. 昭和 39 年 3 月 頃から膀胼洗滌時にカテーテルの挿入が困難となり，同 年 9 月頃から下腹部に腫瘤を触知するようになり悪液質 状態が強度になつて，同年11月21日死亡した．剖検時の 膀胼所見は, 膀脂壁全体が肥厚し, 壊死が強く, 病理組 織学的には squamous cell carcinoma であつた。

症例 20 . 剖検時 47 才, 昭和 16 年 12 月 20 日（当時 21 才) 戦地にて受傷，第 5,6 胸椎骨折兼脊髄損傷を発症す る. 昭和 24 年 3 月頃から血膿尿が生じ始め, 昭和 26 年 8 月には大豆大の結石が自然排出した。そ後血膿尿は一 時改善されたが，昭和 37 年 6 月頃から血膿尿の排尿が始 まり，昭和 40 年 6 月，膀胱鏡検査で膀胱腫瘍を疑い，癌 研究会付属病院にて, Linear Accelerator による9000レ ントゲンの照射治療を受けた。 その後血膿尿は改善され た. 昭和 41 年 6 月, 10 月, 昭和 42 年 6 月, 11 月, 昭和 43 年 2 月の膀胱鏡検査では腫瘍所見を認めなかつた。昭和 42 年 3 月, 11 月の膀脱尿細胞診では, 覀性細胞とみなさ れる細胞は認められなかつたが，昭和 43 年 4 月の膀胱尿
細胞診では悪性細胞とみなされる細胞を認めた（写 1 ）. 昭和 43 年 5 月中頃から急に血膿尿の排尿が増強し, 全身 状態が不良となり，同年 6 月 7 日死亡した。剖検時の膀 胱所見は写真 2 の如く, 膀胼壁全体が非常に肥厚し且つ 硬く, 全周に迫り腫瘍組織で占められて扣り, 壊死も強 い. 病理組織学的には Squamous cell carcinoma の像 を呈している (写3).

症例 21 . 剖検時 46 才, 昭和16年 9 月 15 日（当時19才） 戦地にて受傷，第 7 澒椎骨折兼脊髄損傷を発症する. 受 傷時約 1 カ月間の留置カテーテルを受けたが，その後は 特に排尿困難もなく小康を保つていた．昭和 43 年 7 月中 頃から尿路感染による発熱が生じ始め，全身状態が不良 となり，同年 8 月 27 日死亡した，剖検時の膀胱所見は症 例20と同様に膀胱壁全体が非常に肥厚し且つ硬く全周に 迫り腫瘍組織で占められて㧊り，部分的に強い壊死を認 めた. 病理組織学的には squamous cell carcinoma で あつた. 生前に膀胱尿細胞診を 3 回試みたが悪性細胞は 認められなかつた. 又, 写真 4 は症例 7 の受傷後 12 年 2 カ月経過した膀胱組織像で, 膀胱組織の一部にcolumnar metaplasia を生じている. 写真 5 は症例 8 の受傷後12年. 6 カ月経過した膀胱組織像で squamous metaplasia を 生じている.

\section{ロ.TUR による膀胱頝部組織所見}

Paraplegia で排尿障害を有する 34名の膀胱頝部組織 を病理組織学的に検討した結果，34名中30名 (88.3\%) に膀脱上皮の変化を認めた（表 4 （a），(b)，(c)， (d), (e)).そのらち squamous metaplasia は25名 (73.5\%), Brunn の細胞巣を認めたものは25名 (73.5 \%) である. 残り 4 名は膀脱上皮が脱落していて膀胱上 皮所見が得られなかつたもの 3 名，1名は得られた組織 からは，炎症所見の他は特に異常を認めなかつた．尚， cystitis glanduralis の所見は 1 例も認められなかつた。 又, 悪性腫瘍を思わせる症例も認められなかつた。

paraplegia 発症後の期間と膀胱上皮の変化に関して は, 表 4 （a）の如く, paraplegia 発症後尿路感染を伴 亏場合， 4 力月〜 6 力月位経過すると，膀脱上皮に化生 が起り得ることがうから゙える. 写真 6 は症例 4 の膀胱頝 部生検像で squamous metaplasia を認める. paraplegia 発症後 1 年未満に於ける膀胱上皮化生の発生割合 は, squamous metaplasiaは 7 例中 5 例 $(71.4 \%)$ に, Brunn の細胞巣を認めたものは 7 例中 4 例 $(57.2 \%)$ であつ た. Paraplegia 発症後 1 年以上 5 年末満では, squamous metaplasia は11例中 9 例 $(81.8 \%)$, Brunn の細胞巣を 
写真 1 剖㭘例の症例20, 尿細胞診症例 111例の細 胞診で，濃染する不整形の核をもつた多角 形の異型細胞が認められる。

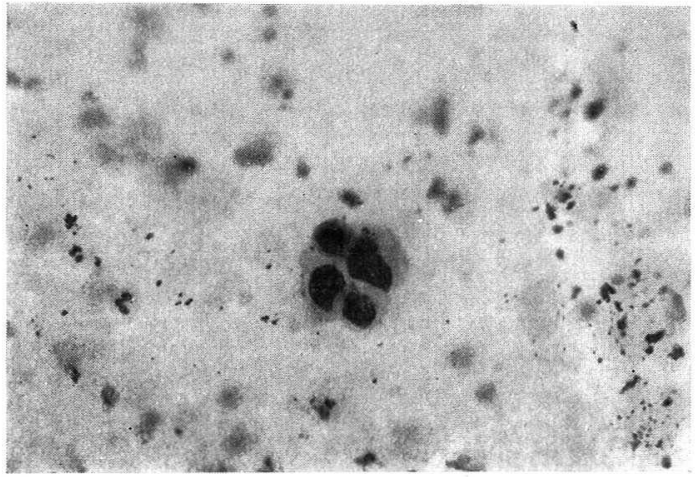

写真 2 剖検例症例 200 膀胱の正中線割面で, 膀胱 壁が全周にわたり腫瘍組織でしめられ，腹 膜，腸の一部まで腫瘄組織が浸潤している。

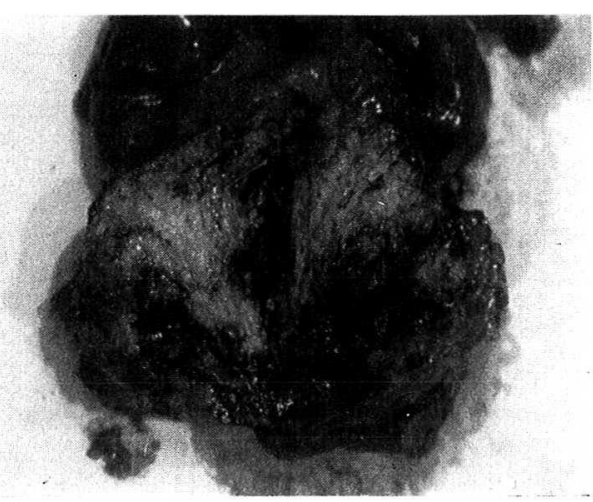

写真 3 剖検例の症例20の膀胱組織像で，角化を伴 う squamous cell carcinoma が認ぬられ る.

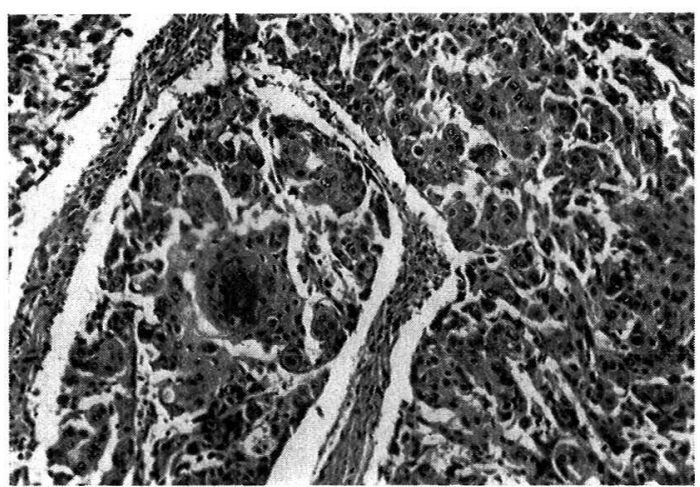

写真 4 剖検例の症例 7 の膀胱組織像で膀胱上皮の 一部に columnar cell からなる腺構造が みられる。

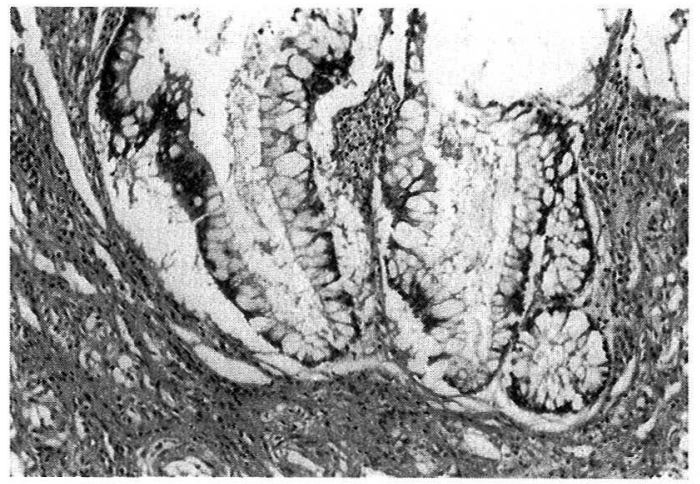

写真 5 剖檢例の症例 8 の膀胱組織像で膀胱上皮の squamous metaplasia がみられ, submucosa に小円形細胞浸潤が軽度に認められる。

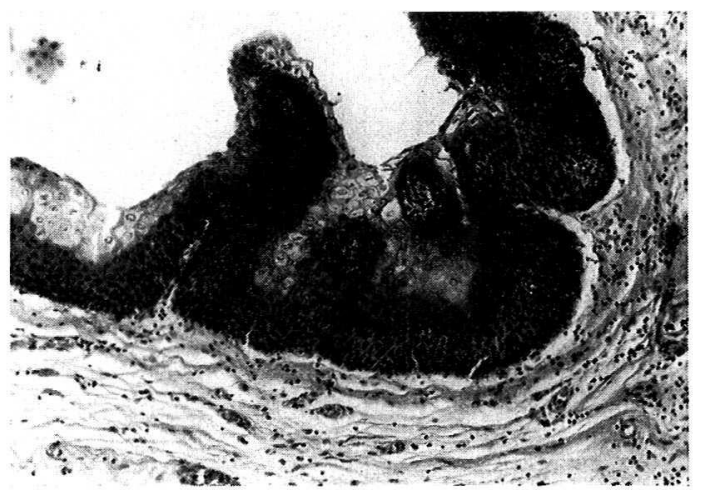

写真 6 膀胱生検の症例 4 の生検像で, 膀胱上皮の squamous metaplasia を認め, transitional cell との移行部がみられる。

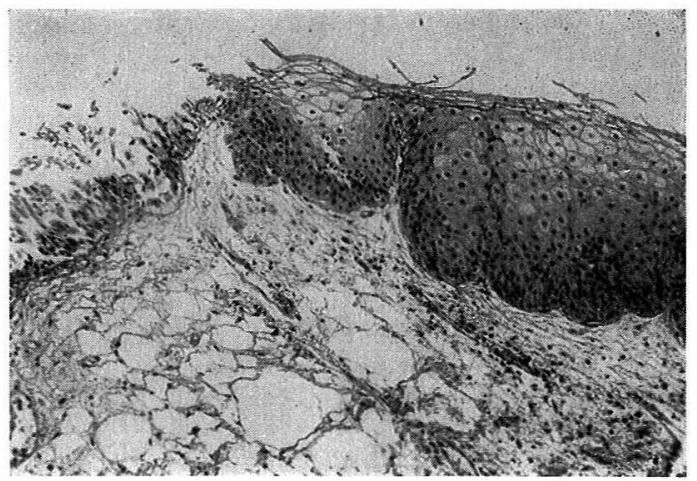


4 (a) 1 年未満

表 4 T U R による膀腅䅡部組織所見

\begin{tabular}{|c|c|c|c|c|c|c|c|c|c|c|c|}
\hline \multirow[b]{2}{*}{ 症例 } & \multirow[b]{2}{*}{ 年令・性 } & \multirow[b]{2}{*}{ 期 間 } & \multicolumn{3}{|c|}{ 膀 胱 組 織 } & \multicolumn{4}{|c|}{ 尿 } & \multirow{2}{*}{$\begin{array}{l}\text { 留置カテ } \\
\text { 学ル } \\
\text { 期間 }\end{array}$} & \multirow{2}{*}{$\begin{array}{l}\text { 膀胱結石 } \\
\text { の既往 }\end{array}$} \\
\hline & & & 炎症 & $\begin{array}{l}\text { Sq. } \\
\text { meta. }\end{array}$ & $\begin{array}{c}\text { Brunn's } \\
\mathrm{N}\end{array}$ & 蛋白 & 白血球 & 細菌 & 残尿 & & \\
\hline 1 & $47 \delta$ & $4 \mathrm{M}$ & + & - & + & $+\sim-$ & $+\sim-$ & $+\sim-$ & + & $1 \mathrm{~W}$ & あり \\
\hline 2 & 27 令 & $6 \overline{\mathrm{M}}$ & + & \multicolumn{2}{|c|}{ 上皮脱落 } & $+\sim+$ & $+\sim+$ & $+\sim+$ & + & $3 \mathrm{M}$ & \\
\hline 3 & 56 古 & $6 \overline{\mathrm{M}}$ & H & + & + & $+\sim+$ & $+\sim+$ & $t \sim+$ & + & $3 \mathrm{M}$ & \\
\hline 4 & $34 \hat{8}$ & $6 \overline{\mathrm{M}}$ & + & $H$ & + & $+\sim+$ & $+\sim+$ & $+\sim+$ & + & $2 \mathrm{~W}$ & \\
\hline 5 & 56 占 & $8 \mathrm{M}$ & + & + & - & $H \sim H$ & $H \sim H$ & $H \sim H$ & + & $4 \mathrm{M}$ & \\
\hline 6 & 47 尔 & $10 \mathrm{M}$ & H & $H$ & + & $+\sim+$ & $+\sim+$ & $t \sim t$ & + & $6 \mathrm{M}$ & \\
\hline 7 & 33 年 & $10 \mathrm{M}$ & + & + & - & $+\sim+$ & $+\sim+$ & $t \sim t$ & + & $4 \mathrm{M}$ & \\
\hline & & & & $\begin{array}{c}5 / 7 \\
(71.4 \%\end{array}$ & $\begin{array}{c}4 / 7 \\
(57.2 \%)\end{array}$ & & & & & & \\
\hline
\end{tabular}

Sq. meta. $=$ Squamous metaplasia, Brunn's N. $=$ Brunn's Nest

$\mathrm{V}=$ 週, $\mathrm{M}=$ 月, $\quad \mathrm{y}=$ 年

4 (b) 1 年以上 5 年未満

\begin{tabular}{|c|c|c|c|c|c|c|c|c|c|c|c|c|}
\hline \multirow[b]{2}{*}{ 症例 } & \multirow[b]{2}{*}{ 年令・性 } & \multirow{2}{*}{ 期 } & \multirow{2}{*}{ 間 } & \multicolumn{3}{|c|}{ 膀 胱 組 織 } & \multicolumn{4}{|c|}{ 尿 } & \multirow{2}{*}{$\begin{array}{l}\text { 留置カテ } \\
\text { 学ル } \\
\text { 期間 }\end{array}$} & \multirow{2}{*}{$\begin{array}{l}\text { 膀胱結石 } \\
\text { の既往 }\end{array}$} \\
\hline & & & & 炎症 & $\begin{array}{c}\text { Sq. } \\
\text { meta. }\end{array}$ & $\begin{array}{c}\text { Brunn's } \\
\text { N. }\end{array}$ & 蛋白 & 白血球 & 細菌 & 残尿 & & \\
\hline 8 & $54 \pi$ & $1 \mathrm{y}$ & $3 \mathrm{M}$ & H & - & + & $+\sim t$ & $\# \sim+$ & $H \sim+$ & $t$ & $8 \mathrm{M}$ & あり \\
\hline 9 & $53 \hat{\jmath}$ & $1 \mathrm{y}$ & $6 \mathrm{M}$ & + & + & + & $+\sim+$ & $H \sim H$ & $H \sim H$ & + & $3 \mathbf{M}$ & \\
\hline 10 & 32 全 & $2 y$ & $2 \mathrm{M}$ & $H$ & \multicolumn{2}{|c|}{ 上皮脱 落 } & $H \sim+$ & it $\sim$ H & $H \sim+$ & $H$ & $9 \mathrm{M}$ & \\
\hline 11 & 29 年 & $2 y$ & $4 \mathrm{M}$ & $\#$ & H & H & $+\sim+$ & $+\sim+$ & $+\sim+$ & + & $2 y$ & あり \\
\hline 12 & 26 分 & $2 y$ & $2 \mathrm{M}$ & H & + & - & $+\sim-$ & $+\sim-$ & $+\sim-$ & + & $4 \mathrm{M}$ & \\
\hline 13 & $50 \hat{0}$ & $2 y$ & $6 \mathrm{M}$ & H1 & $H$ & - & $H \sim+$ & $\mathrm{H} \sim \mathrm{H}$ & $H \sim H$ & H & $3 \mathrm{M}$ & \\
\hline 14 & $21 \hat{0}$ & $2 y$ & $6 \mathrm{M}$ & $H$ & + & $\#$ & $+\sim+$ & $t \sim t$ & $+\sim+$ & + & $6 \mathrm{M}$ & \\
\hline 15 & $32 \hat{0}$ & $3 y$ & & it & + & - & $+\sim-$ & $+\sim-$ & $+\sim-$ & + & $3 \mathrm{M}$ & \\
\hline 16 & 42 古 & $3 y$ & $1 \mathrm{M}$ & + & + & + & $t \sim+$ & $+\sim+$ & $+\sim+$ & + & $2 \mathrm{M}$ & \\
\hline 17 & $51 \hat{0}$ & $3 y$ & $4 \mathrm{M}$ & $H$ & $t$ & $H$ & $t \sim t$ & $t \sim t$ & $t \sim+$ & $t$ & $3 \mathrm{M}$ & \\
\hline 18 & $31 \hat{0}$ & $4 \mathrm{y}$ & $5 \mathrm{M}$ & + & + & + & $+\sim+$ & $+\sim+$ & $t \sim t$ & + & $4 y$ & \\
\hline & & & & & $\begin{array}{r}9 / 11 \\
\times 81.8 \% \\
\end{array}$ & $\begin{array}{c}7 / 11 \\
(63.6 \%) \\
\end{array}$ & & & & & & \\
\hline
\end{tabular}

4 (c) 5 年以上 10 年未満

\begin{tabular}{|c|c|c|c|c|c|c|c|c|c|c|c|c|}
\hline \multirow[b]{2}{*}{ 症例 } & \multirow[b]{2}{*}{ 年令・性 } & \multirow{2}{*}{\multicolumn{2}{|c|}{ 期 }} & \multicolumn{3}{|c|}{ 膀 胱 組 織 } & \multicolumn{4}{|c|}{ 尿 } & \multirow{2}{*}{$\begin{array}{l}\text { 留置カテ } \\
\text { 厂ル } \\
\text { 期間 }\end{array}$} & \multirow{2}{*}{$\begin{array}{l}\text { 膀胱結石 } \\
\text { の既往 }\end{array}$} \\
\hline & & & & 炎症 & $\begin{array}{c}\text { Sq. } \\
\text { meta. }\end{array}$ & $\begin{array}{c}\text { Brunn's } \\
\text { N. }\end{array}$ & 蛋白 & 白血球 & 細菌 & 残尿 & & \\
\hline 19 & $32 \%$ & $6 \mathrm{y}$ & & $t$ & - & + & $+\sim-$ & $+\sim-$ & $+\sim-$ & $t$ & $2 M$ & \\
\hline 20 & 30 令 & $6 y$ & $1 \mathrm{M}$ & H & + & + & $+\sim+$ & $+\sim+$ & $+\sim+$ & + & $3 \mathrm{M}$ & \\
\hline 21 & $43 \hat{\delta}$ & $9 y$ & $2 \mathrm{M}$ & it & H & H & $+\sim+$ & $+\sim+$ & $+\sim+$ & + & $2 \mathrm{M}$ & \\
\hline & & & & & $\begin{array}{r}2 / 3 \\
666.7 \%\end{array}$ & $\begin{array}{c}3 / 3 \\
(100 \%)\end{array}$ & & & & & & \\
\hline
\end{tabular}


4 (d) 10 年以上 20 年未满

\begin{tabular}{|c|c|c|c|c|c|c|c|c|c|c|c|c|}
\hline \multirow[b]{2}{*}{ 症例 } & \multirow{2}{*}{ 年令 - 性 } & \multirow[b]{2}{*}{ 期 } & \multirow{2}{*}{ 間 } & \multicolumn{3}{|c|}{ 膀 胱 組 織 } & \multicolumn{4}{|c|}{ 尿 } & \multirow{2}{*}{$\begin{array}{l}\text { 留置カテ } \\
\text { 厂ルの } \\
\text { 期間 }\end{array}$} & \multirow{2}{*}{\begin{tabular}{|l} 
膀胱結石 \\
の既往
\end{tabular}} \\
\hline & & & & 炎症 & $\begin{array}{c}\text { Sq. } \\
\text { meta. }\end{array}$ & $\begin{array}{c}\text { Brunn's } \\
\text { N. }\end{array}$ & 蛋白 & 白血球 & 細菌 & 残尿 & & \\
\hline 22 & $31 \hat{\delta}$ & $10 \mathrm{y}$ & & + & - & + & $+\sim+$ & $t \sim+$ & $+\sim+$ & + & $2 \mathrm{M}$ & \\
\hline 23 & 36 令 & $10 \mathrm{y}$ & $1 \mathrm{M}$ & $H$ & + & $H$ & $+\sim+$ & $+\sim+$ & $+\sim+$ & $H$ & $3 y$ & \\
\hline 24 & $36 \hat{8}$ & $10 \mathrm{y}$ & $9 \mathrm{M}$ & $H$ & $H$ & $H$ & $H \sim+$ & $H \sim+$ & $H \sim H$ & $H$ & 0 & \\
\hline 25 & 52 个 & $11 \mathrm{y}$ & $1 \mathrm{M}$ & $H$ & - & - & $+\sim+$ & $+\sim+$ & $+\sim+$ & + & $2 \mathrm{M}$ & \\
\hline 26 & $52 \hat{0}$ & $13 y$ & & $H$ & H & $H$ & $+\sim+$ & $+\sim+$ & $+\sim+$ & $H$ & $6 \mathrm{M}$ & \\
\hline 27 & $37 \hat{\delta}$ & $17 \mathrm{y}$ & $1 \mathrm{M}$ & + & + & $H$ & $+\sim+$ & $+\sim+$ & $+\sim+$ & + & $6 \mathrm{M}$ & \\
\hline 28 & $60 \hat{0}$ & $19 y$ & $3 \mathrm{M}$ & $H$ & + & $H$ & $+\sim+$ & $+\sim+$ & $+\sim+$ & + & $4 \mathrm{M}$ & \\
\hline & & & & & $\begin{array}{c}5 / 7 \\
(71.4 \%\end{array}$ & $\begin{array}{c}6 / 7 \\
(85.7 \%)\end{array}$ & & & & & & \\
\hline
\end{tabular}

4 (e) 20 年以上

\begin{tabular}{|c|c|c|c|c|c|c|c|c|c|c|c|c|}
\hline \multirow[b]{2}{*}{ 症例 } & \multirow[b]{2}{*}{ 年令 - 性 } & \multirow[b]{2}{*}{ 期 } & \multirow[b]{2}{*}{ 間 } & \multicolumn{3}{|c|}{ 膀 胱 組 織 } & \multicolumn{4}{|c|}{ 尿 } & \multirow{2}{*}{$\begin{array}{l}\text { 留置カテ } \\
\text { 其ルの } \\
\text { 期間 }\end{array}$} & \multirow{2}{*}{$\begin{array}{l}\text { 膀胱結石 } \\
\text { の 既往 }\end{array}$} \\
\hline & & & & 炎症 & $\begin{array}{c}\text { Sq. } \\
\text { meta. }\end{array}$ & $\begin{array}{c}\text { Brunn's } \\
\text { N. }\end{array}$ & 蛋白 & 白血球 & 細菌 & 残尿 & & \\
\hline 29 & $56 \hat{0}$ & $21 \mathrm{y}$ & $6 \mathrm{M}$ & $H$ & $H$ & + & $t \sim t$ & $t \sim t$ & $t \sim t$ & + & 0 & \\
\hline 30 & 50 令 & $24 \mathrm{y}$ & $6 \mathrm{M}$ & H & + & + & $+\sim+$ & $+\sim+$ & $+\sim+$ & + & $5 \mathrm{M}$ & \\
\hline 31 & $54 \hat{0}$ & $24 \mathrm{y}$ & $6 \mathrm{M}$ & $H$ & \multicolumn{2}{|c|}{ 上皮脱落 } & $H \sim H$ & $H \sim H$ & $H \sim H$ & H & 0 & \\
\hline 32 & $50 \hat{0}$ & $25 y$ & $2 \mathrm{M}$ & + & - & + & $+\sim+$ & $+\sim+$ & $t \sim+$ & + & 0 & \\
\hline 33 & $47 \hat{8}$ & $27 \mathrm{y}$ & $2 \mathrm{M}$ & H & + & + & $+\sim+$ & $+\sim+$ & $+\sim+$ & + & $7 y$ & \\
\hline 34 & $50 \hat{0}$ & $28 \mathrm{y}$ & $3 \mathrm{M}$ & $H$ & + & + & $H \sim H$ & $H \sim H$ & $H \sim H$ & + & 0 & \\
\hline & & & & & $\begin{array}{c}4 / 6 \\
(66.7 \%)\end{array}$ & $\begin{array}{c}5 / 6 \\
(83.3 \%) \\
\end{array}$ & & & & & & \\
\hline
\end{tabular}

表 5 炎症の程度と上皮化生との関係

\begin{tabular}{|c|c|c|c|c|c|c|}
\hline \multirow{2}{*}{$\begin{array}{l}\text { 炎症の } \\
\text { 程 度 }\end{array}$} & \multirow{2}{*}{ 例数 } & \multicolumn{2}{|c|}{ Sq. Meta. } & \multicolumn{2}{|c|}{ Brunn's Nest } & \multirow{2}{*}{$\begin{array}{l}\text { 上皮 } \\
\text { 脱落 }\end{array}$} \\
\hline & & $H \sim+1$ & - & $H \sim+1$ & - & \\
\hline$H$ & 22 & $\begin{array}{c}18 \\
(81.8 \%)\end{array}$ & 2 & $\begin{array}{c}15 \\
(68.2 \%)\end{array}$ & 5 & 2 \\
\hline+ & 12 & $\begin{array}{c}7 \\
(59.2 \%)\end{array}$ & 4 & $\begin{array}{c}10 \\
(83.3 \%)\end{array}$ & 1 & 1 \\
\hline
\end{tabular}

認めたものは 11 例中 7 例 $(63.6 \%)$ で，5 年以上 10 年未 満では squamous metaplasia は3 例中 2 例 $(66.7 \%)$, Brunn の細胞巣は 3 例中 3 例に，10年以上 20 年末満 で は, squamous metaplasiaは 7 例中 5 例 $(71.4 \%)$, Brunn の細胞巣は 7 例中 6 例 $(85.7 \%), 20$ 年以上経過した症例 では, squamous metaplasia は 6 例中 4 例 $(66.7 \%)$ に, Brunn の細胞巣は 6 例中 5 例 $(83.3 \%)$ であつた. この様に paraplegiaの膀胧上皮は尿路感染を伴う場合， 6 カ月以上経過すると，その経過年数と関係なく膀胼上
表 6 細菌尿の程度と上皮化生との関係

\begin{tabular}{c|c|c|c|c|c|c}
\hline \multirow{2}{*}{$\begin{array}{c}\text { 細菌尿 } \\
\text { の程度 }\end{array}$} & 例数 & \multicolumn{2}{|c|}{ Sq. Meta. } & \multicolumn{2}{|c|}{ Brunn's Nest } & 上皮 \\
\cline { 2 - 6 } & $+\sim+$ & - & $H \sim+$ & - & 脱落 \\
\hline+ & 8 & $\begin{array}{c}5 \\
(62.5 \%)\end{array}$ & 1 & $\begin{array}{c}4 \\
(50 \%)\end{array}$ & 2 & 2 \\
\hline+ & 26 & $\begin{array}{c}20 \\
(76.9 \%\end{array}$ & 5 & $\begin{array}{c}21 \\
(80.8 \%)\end{array}$ & 4 & 1 \\
\hline
\end{tabular}

皮に高頻度に化生が生じている成績結果が得られた。膀 腅の炎症程度と膀胱上皮化生の関係について調べてみる と 膀胱炎症所見の程度が強い方が, 炎症程度の弱い方 よりも， squamous metaplasia が生じている割合が大き $く$, Brunn の細胞巣の出現は膀脱の炎症程度にはあまり 関係なかつた（表 5 ）。

細菌尿の程度と膀脂上皮化生との関係についてみる と, 細菌尿の程度が強いと膀胱上皮の脱落が生じてい て, かえつて膀胱上皮化生の発生割合が少ない結果が得 
表 7 残尿の程度と上皮化生との関係

\begin{tabular}{c|c|c|c|c|c|c}
\hline \multirow{2}{*}{$\begin{array}{c}\text { 残尿の } \\
\text { 程 度 }\end{array}$} & 例数 & \multicolumn{2}{|c|}{ Sq. Meta. } & \multicolumn{2}{|c|}{ Brunn's Nest } & 上皮 \\
\cline { 2 - 6 } & $+4 \sim+$ & - & $H \sim+$ & - & 脱落 \\
\hline+ & 7 & $\begin{array}{r}5 \\
(71.4 \%)\end{array}$ & 0 & $\begin{array}{r}4 \\
(57.1 \%)\end{array}$ & 1 & 2 \\
\hline+ & 27 & $\begin{array}{r}20 \\
(74.1 \%)\end{array}$ & 6 & $\left.\begin{array}{r}21 \\
(77.8 \%\end{array}\right)$ & 5 & 1 \\
\hline
\end{tabular}

られた（表 6).しかしこの場合でも膀胱上皮が再生され る場合には, 膀胼上皮化生が生じている可能性は十分に 考えられる. 残尿の程度と膀胱上皮化生との関係につい ては, 残尿が50ml 〜 100ml 位までの場合と $100 \mathrm{ml}$ 以 上の場合との関係では, 膀脂上皮化生の発生割合は差が なかつた（表 7 ).

留置カテーテルの期間と膀胱上皮化生との関係につい てみると, カテーテル留置期間が長い程, 膀脱上皮化生 が生じている割合が大きい成績結果が得られた（表 8 ）。

表 8 留置カテーテルの期間と上皮化生との関係

\begin{tabular}{|c|c|c|c|c|c|c|}
\hline \multirow{2}{*}{$\begin{array}{l}\text { 留置カテ } \\
\text { テテルの } \\
\text { 期間 }\end{array}$} & \multirow{2}{*}{ 例数 } & \multicolumn{2}{|c|}{ Sq. Meta. } & \multicolumn{2}{|c|}{ Brunn's Nest } & \multirow{2}{*}{$\begin{array}{l}\text { 上皮 } \\
\text { 脱落 }\end{array}$} \\
\hline & & $H \sim+$ & 一 & $H \sim+$ & - & \\
\hline 0 力月 & 5 & $(60 \%)$ & 1 & $\begin{array}{c}4 \\
(80 \%)\end{array}$ & 0 & 1 \\
\hline $\begin{array}{l}\text { 1 6力 } \\
\text { 月末満 }\end{array}$ & 20 & $(75 \%)$ & 4 & $\begin{array}{c}13 \\
(65 \%)\end{array}$ & 6 & 1 \\
\hline $\begin{array}{l}6 \text { 力月 } \\
\text { 以 }\end{array}$ & 9 & $(77.8 \%)$ & 1 & $(88.9 \%)$ & 0 & 1 \\
\hline
\end{tabular}

\section{八. 膀朕尿細胞診の成績（表 9 （a ），(b)）}

Paraplegia 134名の膀胱尿細胞診を昭和 42 年 1 月から 昭和 43 年 7 月までの 1 年 7 カ月間に $5 \sim 6$ カ月間隔で 2 〜 3 回行なつた成績結果は表 9 (a), 9 (b),の如く, 扁平上皮細胞の出現を認めたものは85名 (63.4\%) であ る. 排尿障害を有する paraplegia の膀脱頝部を TUR で切除した34名の膀胱尿細胞診の成績は, 膀脱生検所見 と一致したものは，22名の squamous metaplasia を有す る中で, 扁平上皮細胞の出現を認めたものは17名（77.3 \%) である. 逆に膀胱尿細胞診で扁平上皮細胞の出現を 認め, 膀胱生検では膀胱上皮が脱落しているものが 2 名 あつた. TUR の膀脂生検を施行していない100名の中 で，排尿障害（残尿 $150 \mathrm{ml}$ ) を有するが TUR を拒む 1 名を除き, 残り99名は現在の所, 残尿 $50 \mathrm{ml}$ 以上を持
つていない，膀胱尿細胞診という検査法に信頼度がある とすると，99名中62名（62.6\%）の膀胱上皮に squamous metaplasia が生じている可能性が推測される. これら 62名は慢性尿路感染は持つているが, 結石, 留置カテ 一テル等の異物は現在持つていない。乙かも排尿障害 （50ml 以上の残尿）がなくても，膀脱上皮に squamous metaplasia が生じていることがうから゙い得る. 又, 悪性 細胞は 134名中 1 名に認め, この症例は剖検例の20症例 であつた。

\section{総括及び考案}

従来, 膀胱に長期間慢性感染, 刺激, 異物などが存 続すると, 膀脱上皮に metaplasia（化生）が生ずること はよく知られた事実である. 又, 膀脱化生上皮と膀脱癌 の発生との関係は, 腺性化生から腺癌, 表皮様化生から 扁平上皮癌が発生すると云う議論が多数ある. 腺性膀脱 炎や, 膀胱白板症は potential malignant で癌前駆症と みなすべきと説く人もある(1)718)20130)31)。これら膀胱上 皮化生の発生原因は，長期間の慢性感染 結石や寄生虫 等の物理的, 化学的刺激が, 何らかの形で関与し, これ らの刺激が一つの大きな要因であることは多数の人々が 認める所である。

又, 膀脂外反症の様な特殊な環境に置かれた膀脂上皮 は，炎症性刺激によつて生ずる上皮化生とはやや趣を異 にし, Culp $(1964)^{7)}$ によると, 生後 1 カ月から52才ま での33例の膀胼外反症の膀脱上皮を組織学的に検索した 結果, 正常膀胱組織を有するものは 1 例もなく, squamous metaplasia を伴うもの18例, cystitis cystica を有 するものは15例, glandular formation を伴うものは18例 で，52才の症例は adenocarcinoma であつたと述べてい る. 又，3才以上経過しているものは全例に columnar metaplasia を伴つていたと記載している. McIntosh, Worley (1955) ${ }^{24)}$ は文献上40例の膀胱外反症の膀胱癌を 集め, 膀胱癌組織の分類されている35例中33例 (94\%) が adenocarcinomaで, 2 例が squamous cell carcinoma であつたと述べている. その平均年令は44才で, 最も若 いものは21才であつて，長期間の絶えることのない感 染と外界との接触がその主要因であると述べている. Goyanna, Emmett(1951) ${ }^{15)}$, McIntosh, Worley (1955) ${ }^{24)}$, Culp $(1964)^{7)}$ らはそれぞれ，170例中 7 例 $(4.1 \%), 25$ 例中 2 例 $(8 \%), 23$ 例中 1 例 $(4.4 \%)$ の膀胱外反症の adenocarcimonaを報告している.

一方, 英国の Stoke Mandeville Hospital で, Melzak $(1966)^{26)}$ が8800名の paraplegia から11名 $(0.28 \%)$,カ 
表 9 膀脂尿細胞診の成績

9 (a)

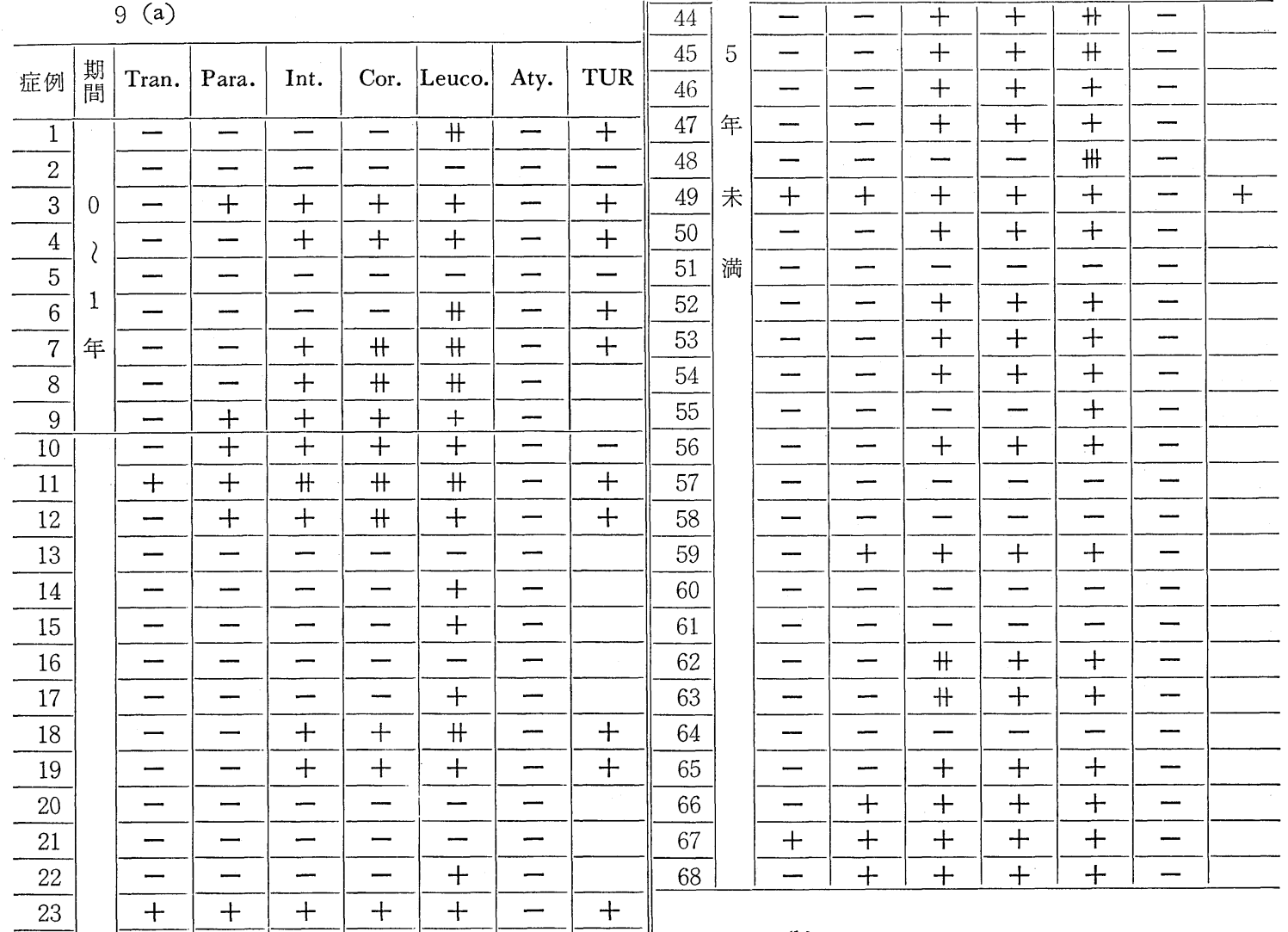




\begin{tabular}{|c|c|c|c|c|c|c|c|c|c|c|c|c|c|c|c|c|c|}
\hline 86 & \multirow{2}{*}{$\begin{array}{l}\text { 以 } \\
\text { 上 }\end{array}$} & - & - & - & - & + & - & & 111 & \multirow[b]{2}{*}{ 年 } & - & + & + & H & H & + & \\
\hline 87 & & - & - & + & + & + & - & & 112 & & + & + & $H$ & $H$ & $H$ & - & + \\
\hline 88 & 上 & - & - & - & - & + & - & & 113 & \multirow{4}{*}{ 以 } & - & + & $H$ & + & + & - & \\
\hline 89 & \multirow{2}{*}{$\begin{array}{l}15 \\
\text { 年 }\end{array}$} & - & - & - & - & - & - & & 114 & & - & + & H & $H$ & + & - & \\
\hline 90 & & - & - & - & - & - & - & & 115 & & + & + & $H$ & $H$ & + & - & \\
\hline 91 & \multirow{4}{*}{$\begin{array}{l}\text { 未 } \\
\text { 满 }\end{array}$} & - & - & + & + & $H$ & - & & 116 & & + & + & H & $H$ & + & - & \\
\hline 92 & & - & + & + & + & + & - & & 117 & \multirow[t]{3}{*}{ 上 } & - & - & + & + & + & - & \\
\hline 93 & & - & - & - & - & H & - & & 118 & & - & - & - & - & + & - & \\
\hline 94 & & - & - & + & + & + & - & & 119 & & - & - & - & - & + & - & \\
\hline 95 & \multirow{4}{*}{$\begin{array}{l}15 \\
\text { 年 }\end{array}$} & - & - & + & + & + & - & + & 120 & & - & - & - & - & - & - & \\
\hline 96 & & - & - & H & H & + & - & & 121 & & - & - & - & - & + & - & \\
\hline 97 & & - & - & + & + & + & - & & 122 & & + & + & + & + & + & - & \\
\hline 98 & & - & - & + & + & + & - & & 123 & & - & - & - & - & + & - & \\
\hline 99 & \multirow{2}{*}{ ) } & - & - & + & H & + & - & & 124 & & H & H & H & H & + & - & \\
\hline 100 & & - & + & + & H & + & - & + & 125 & & - & - & - & - & - & - & \\
\hline 101 & \multirow{2}{*}{$\begin{array}{l}20 \\
\text { 年 }\end{array}$} & + & + & + & + & + & - & & 126 & & - & H & \# & $H$ & $H$ & - & \\
\hline 102 & & - & - & - & - & - & - & & 127 & & - & - & $H$ & $H$ & + & - & \\
\hline 103 & 未 & - & - & - & - & H & - & - & 128 & & - & + & H & + & + & - & \\
\hline 104 & \multirow{3}{*}{ 満 } & - & - & - & - & W & - & & 129 & & - & - & + & + & + & - & \\
\hline 105 & & - & - & + & + & + & - & & 130 & & - & - & - & - & - & - & \\
\hline 106 & & - & - & - & - & + & - & + & 131 & & + & + & + & + & + & - & \\
\hline 107 & \multirow[b]{3}{*}{20} & + & + & + & H & \# & - & + & 132 & & - & - & - & - & - & - & \\
\hline 108 & & - & $\frac{t}{t}$ & + & $\frac{+}{4}$ & $\frac{\pi}{4}$ & - & & 133 & & - & - & - & - & $\mathrm{W}$ & - & \\
\hline$\frac{109}{110}$ & & - & $\frac{+}{-}$ & $\frac{H}{H}$ & $\frac{H}{t}$ & $\frac{H}{t}$ & $\frac{-}{-}$ & - & 134 & & - & + & + & + & + & - & \\
\hline
\end{tabular}

Tran. $=$ Transitional cell, $P$ ara. $=$ Parabasal cell, Int. $=$ Intermediate cell,

Cor. $=$ Cornified cell, Aty. $=$ Atypical cell, Leuco. =Leucocyte

TUR (十) は膀胱顏部生検にて Squamous metaplasiaを認める.

ルフオルニヤ，ロングビーチの V.A. Hospital では, Nyquist, Bors (1967) ${ }^{29}$ が1851名の paraplegia の中から 5 名 $(0.27 \%)$ の膀羘癌を発見し, 共に non-paraplegia に比して膀脱癌の発生頻度が高いと報告し, その原因は 慢性尿路感染が大きな要因であると述べている（表10）. Melzak (1966) ${ }^{26)}$ によると11名の膀脱癌のうち4名が squamous cell carcinoma, 3 名が transitional cell と squamous cell との混合, 4 名が transitional cell carcinoma である. 著者は国立箱根療養所の paraplegia 267 名中 4 名 ( $1.5 \%)$ の膀胱癌を経験した. その病理組織 は4名中 3 名が squamous cell carcinoma であつた. 1964年の厚生省の統計によると，本邦人の膀腅癌による 死亡が人口 10 万人に 1.3 人 $(0.0013 \%)$ 以下であるのに 比して, paraplegia に於ける膀胼癌による死亡は1000倍 に近い高率である. しかも，年令が比較的若く，47才， 48才，47才，50才で, Melzak の症例では30才代が 3
表10 Incidence of neoplasm in the patients with chronic bladder inflammation

\begin{tabular}{|c|c|c|c|}
\hline & $\begin{array}{l}\text { No. of } \\
\text { pat. }\end{array}$ & Neoplasm & $\%$ \\
\hline $\begin{array}{l}\text { V.A. Hospital } \\
\text { California }\end{array}$ & 1851 & 5 & 0.27 \\
\hline $\begin{array}{l}\text { Stoke Mandeville } \\
\text { Hospital }\end{array}$ & 3800 & 11 & 0.28 \\
\hline $\begin{array}{l}\text { Hakone Spinal } \\
\text { Inj. Center }\end{array}$ & 267 & 4 & 1.5 \\
\hline \multicolumn{4}{|l|}{ Bladder Exstrophy } \\
\hline McIntosh et al & 25 & 2 & 8.0 \\
\hline Goyana et al & 170 & 7 & 4.1 \\
\hline Culp & 23 & 1 & 4.4 \\
\hline
\end{tabular}

名, Nyquist, Bors の症例でも 30 才代が 1 名含まれてい る. Paraplegia の受傷後期間は, 19年 26年間, Melzak の症例では 13 年 42 年間, Nyquist, Bors の症例では 12 年 
〜20年間にわたつている.一般に non-paraplegia の膀胱 癌の大部分は移行上皮癌で, squamous cell carcinoma は4〜 7\%, adenocarcinoma は1〜2\%に過ぎないと 云われている. どうして paraplegia や，膀胖外反症な ぞの様な特殊な環境に置かれた膀胼に高頻度に膀胱癌, 特に異所性の膀朕癌が発生し易いのか, 興味ある点であ るが，その確実な原因はまだ不明である，又，常時感 染を有しながら，なぜ, paraplegia の場合は squamous cell carcinoma が, 又, 膀脱外反症の場合にはadenocarcinoma が多いかという問題についても推論の域を出な いのであるが，両者の相違点を推論すると次の様にな る.

膀脱外反症の場合は，1）常に外気に酒らされている こと，又，衣類，牧むつなどによる物理的刺激が長期間 におよぶこと，2）正常な膀脂の働き（尿を一時蓄める 作用）を有していないこと，3）発生学的にすで異常 を伴つている可能性等が考学られる.

Paraplegia の膀胱は，感染は伴つているが，1）外気 に酒らされることなく，2） ある程度の正常な作用（或 程度の膀胱内圧を有して尿を蓄める働き）を有する．3） 発生学的異常を伴つている可能性はないが, 後天的代謝 系の異常は否定出来ず，時に結石，留置カテーテル等の 異物が介在する点である. 膀胱外反症の場合に於いて, すでに発生学的に異常があつてその為にadenocarcinoma が発生する可能性があるが, Enderlen(1904) ${ }^{11)}$ は出産時 に死亡した膀胱外反症の膀胱上皮は transitional epithelium で拈扮われている症例を報告している.

又, Formiggini $(1920)^{13)}$ とよると生後 9 日目の膀脂 外反症の膀胱上皮に腺様上皮を認めていない. Ashoff $(1928)^{21}$ も新生児の膀胱外反症の膀脂上皮は正常の移行 上皮であつたと述べており，これらの報告から発生学的 に異常があつて, その為に膀胱外反症に於いて adenocarcinoma が発生し易いという考方方は根拠に乏しい感が ある. 膀脱外反症の場合の膀胱上皮は慢性感染も伴うな らが，それよりも外気に酒らされ，扣むつや衣類に刺激 され，尿を一時蓄める作用を失つて一定の膀胱内压を有 していない環境で膀脱上皮再生がくりかえされている. この様な異常な環境のもとで, 膀胱上皮が metaplasiaを 生ずる場合, 膀胱上皮をよりよく保護する様沾液を産 する細胞を持つ columnar metaplasia を伴う方向を取る ことが合目的の様に思われる. 本症では， squamous metaplasiaを伴つている場合もあるが, columnar metaplasia の方が優性に現われるのはこの様な特殊環境に由来する
のではなかららか、ここに興味ある報告がある. Laskowski, Scott $(1965)^{23)}$ らは, paraplegiaの尿路变更に, 膀脱 壁を直接皮膚に出す cutaneous vesicostomy を45例に施 行し，3 年間の観察後，at random にその膀脂弁を組織 学的に検査している. その全例に squamous metaplasia を認めている. 又, 2 例に cystitis glanduralis を認めて いる. この所見は外界との接触の為に膀胱外反症に於け ると同様に，更に保護作用を有する粘液を産する columnar metaplasia の方向に進んだものと解釈している.

病理学的には metaplasia とは本来可逆性, 回復性を もつ上皮の変化とされて和り，上述の原因が去れば，正 常上皮に回復するものであり，それ自体何ら悪性度を持 たないものである. 然し乍ら，その原因が長期間存続す ると, 上皮の変化は可逆性を次第に弶失するのみなら ず，悪性新生物の母台となることがあり，この様な環境 そ掓る metaplasia は potential melignant と云い得る と説明されているーRobbins (1967) ${ }^{34)}$.

膀脂上皮以外の臟器組織の上皮に metaplasia が発生 することがあることは病理学書に多く記載されて拈り， 気管支, 子宮䅡部, 卵管, 唾液腺, 胆のうなどの粘膜上 皮, 或は口腔, 口唇の粘膜上皮などがその好発部位と されている.これらはいづれも分化度の高い columnar type の上皮を母台としており，発生する metaplasia は より分化度の低いとされている squamous type の上皮 化生の方向をとるのが通常である. squamous cell の方 が外界からの刺激に対する抵抗性が強いといらことがこ の現象に対する合目性とされる一方，これらの正常上皮 は粘液産生と云う本来のその臟器に必要とされている重 要な機能を喪失している点では決して生体に有利な変化 とは云えないのである. 又, squamous cell の代表的組 織である皮膚に，外界からの継続的刺激が加わつた場合 の反応変化については, より分化度の高い columnar 或 は adenomatous な分化が起ることは殆んと無いのであ つて, 従つて, 皮膚に発生する悪性腫瘍も本来上皮が有 している squamous cell 或はbasal cell のそれであり, ademocarcinoma が発生することは殆んと無いとされ ている. それに対して，膀脱上皮が，squamous cell と columnar cell との中間に位する transitional cell であ ることは metaplasia がいづれの方向をもとりらるこ と, 又, 悪性化する際, どちらの型の悪性細胞も発生し 得ることが，他の蔵器組織に見られない膀脱上皮の特性 であると云うことができる.

Paraplegia の膀胱に squamous cell carcinoma が発 
生した頻度は，著者は 4 例中 3 例 $(75 \%)$ ， Melzak $(1966)^{26)}$ は 11 例中 3 例 $(36.4 \%)$,移行上皮との混合型 を加光ると7例 (63.7\%) で非常に squamous cell carcinoma が高率である. 又, Dimmette et al $(1958)^{8)}$ ら は, Schistosomiasis に於いても55.5\% 亿 squamous cell carcinoma を認めている，その原因は慢性炎症と異物の 反応であると結論している. 一方, 膀脂白板症の場合, その病因論はいろいろの説であり, 慢性感染, 刺激, ビ タミン $\mathrm{A}$ 欠乏, ホルモンのアンバランス等が指摘されて いるが, 主流は慢性感染刺激説がある. しか子膀脱白板 症は前癌状態とみなされて抢り，尿路に括ける potential malignant metaplasia の代表例とされている. Holley et al (1961) ${ }^{19)}$, O'Flynn (1967) ${ }^{30)}$ らは膀脂白板症を経 過観察中に squamous cell carcinoma になつた症例を報 告している. 彼等らによると, 膀胱白板症から squamous cell carcinoma になるのは10〜20\%位である. しかし全 ての膀胱白板症が squamous cell carcinoma へ移行する ものでもなく，又，慢性尿路感染を伴うもの全てが膀脱 白板症になるものでもない. 慢性感染の他に, 何か未知 の要因があつて膀脂白板症が生じ，そこに何らかの要素 が加つた場合に， squamous cell carcinoma に移行する と考兄られている. 即ち, 膀脱上皮再生過程に於いて， 正常の型の上皮は再生しにくくなり，感染刺激に対して より保護作用を有する分化度の低い角化細胞型になつて 行くとみなされている. paraplegia 患者の膀胱では，膀 胱鏡的に白板症特有のいわゆる “snow flakes” の像を見 ることは殆んどないにも拘らず，組織学的に膀胱上皮を 調べると, squamous metaplasia を呈するものが多いこ とは, 方向として同種の sqamous metaplasia でも, paraplegia と non-paraplegia との間に臨床像が可成の 相違があるのであつて，この点も paraplegia の特性と いえるかも知れない。

著者は次の如き仮説を提案したい, 即ち, 膀胱上皮に 慢性感染, 刺激が長期間加つた場合, これらに対して膀 脱上皮自身の再生過程に於いて, 膀胱上皮の置かれた環 境により，よりよく膀胼上皮を保護する様に metaplasia を生ずる. その方向は, squamous metaylasia 或は columnar metaplasia のいら゙れの方向も取り得る. これら は各独立的に, あるいは相平行して発生すると考光ら れる. その方向を決定するのは, 膀胱上皮が置かれた環 境で，よりよく保護される様に膀胱上皮自身が決める. この metaplasia への変化に前述の慢性刺激が役割を演 ずることは疑い得ない。
Paraplegia の膀胱上皮も, 膀脂外反症の膀胱上皮も， いずれの方向にも metaplasia を生じ得る. 膀胱外反症 の場合は，本来の尿を蓄める作用は失われ，外界との 接触の為に粘液を産して膀胱上皮を保護する columnar metaplasia の方向が優先される. 一方, paraplegia の膀 脱は外界に接していないで，尿を一時蓄めることにより 膀脱内圧を有するので, その再生過程に於いて, 分化度 の低い squamous metaplasia を生じて膀脱上皮を保護 する方向が優先される. これらの metaplasia の生じた 膀脱上皮に何らかの未知の要因が加つた場合にそれぞれ の異所性の癌が発生する. 即ち何か発癌因子が加つた場 合，化生膀胱上皮は，それ対する反応性が他の部位の 上皮に比して大であると考学られる. 著者は paraplegia の膀脱上皮の動態を膀朕尿細胞診, 膀胱生検, 剖検等で 検索した. 膀胱尿細胞診では，134名中85名（63.4\%) に扁平上皮化生が得られた. 写真 1 は剖検例 20 症例の尿 細胞診であるが，malignant cell を得ている. 剖検時の 膀胱組織からは， squamous metaplasia から squamous cell carcinoma に変化してゆく過程の像は得られなかつ た. squamous metaplasiaを伴つている場合の尿所見は， 尿路感染の強弱の程度にはあまり差がなく, paraplegia 受傷後尿路感染を伴う場合には，5～6カ月位から， squamous metaplasia が発生している結果が得られた. 膀脂生検では34名の排尿障害を有する膀胱䅡部の生検で 25名 $(73.5 \%$ ) の膀脱上皮の squamous metaplasia 認め, paraplegia 発症後 6 カ月目にすでに squamous metaplasia が生じている.この結果は膀胱尿細胞診と略 一致している. Squamous metaplasia の発生頻度は, 尿 路感染, 残尿の程度にはあまり関俰なく, 留置カテーテ ルの期間が長い程, 又, 膀胱炎症所見が強い程, 高い結 果が得られた. 剖検の膀胱組織では, 21名の膀脱に於 いて, 6 名の squamous metaplasia, 1 名の部分的 columnar metaplasia, 4 名の膀胼癌 引ち 3 名の sqamous cell carcinomarを認めた. 4 名の膀胱癌患者はいずれも 膀胼結石を伴つたことがある. paraplegia の膀脱に， Squamous cell carcinoma が多いことは, 同じ様に慢性 尿路感染, 刺激に酒らされている膀胱外反症における adenocarcinomaが多いことと対照的な現象である. 著者 は, paraplegia の膀胱上皮は, 慢性感染, 刺激, 異物等 に対して, その再生過程に於いて, 本来の移行上皮に再 生されにくくなり，より保護作用を有する扁平上皮細胞 へと化生される様になりこの状態に何か未知の発癌因 子が加わつた場合に squamaus cell carcinoma が発生す 
ると考觉る． paraplegia の正常膀胱上皮から squamous metaplasia へと変化してゆく過程，更にとこから neoplasm 飞進展する過程飞打いて，慢性尿路感染，異物等 の刺激が一つの重要な要素であると考光る.

\section{結 語}

Paraplegia の膀胱上皮の動態を, 膀脱尿細胞診, 膀胱 頝部生検，剖検膀胱組織を用いて，検討した結果次の如 き結果が得られた。

1. 膀胱尿細胞診 134名中85名 $(63.4 \%)$ 飞扁平上皮 細胞の出現を認めた.

2. 排尿障害を有する膀脱䅡部生検 34 名中 25 名（73.5 \%)に squamous metaplasia を認めた. この squamous metaplasia は paraplegia 受傷後 $5 \sim 6$ カ月位で生じてい る.

3. 昭和 24 年 4 月から昭和 43 年 8 月までに国立箱根療 養所で加療された 267名の paraplegia 中48名死亡した. その全例に剖検を施行しているが，膀胱組織が得られた 21 検体の膀胱組織中に，6名の squamous metaplasia と, 4 名の膀脱癌を認め, その 4 名中 3 名は squamous cell carcinoma であつた. 又, 1 名に部分的に columnar metaplasia を認めた.

4. Non-paraplegia に比して, paraplegia の膀胱に膀 胱癌の発生頻度が非常に高率であり, その膀胱癌は組織 学的には異所性の膀脱癌 (Squamous cell carcinoma) が 多いことが判つた。

以上の結果から, paraplegia の膀胱上皮は, 慢性尿路 感染, 結石やカテーテル等の異物の刺激により膀脱上皮 化生が生じ易く，しかもその方向はsquamous metaplasia が主流であることが判つた. paraplegia の膀脂と同様に 慢性尿路感染，外界の刺激にさらされている膀脱外反症 の場合には columnar metaplasia, adenocarcinoma が主 であるのと対照的な現象である. Paraplegia の正常膀脱 上皮から squamous metaplasia へと変化する過程, 更 に, 時に, neoplasm飞進展する過程に於いて, 慢性尿路 感染，異物等の刺激が一つの重要な要因と考觉る.

（終りに当り，本論文に御指導御校閲下さつた高井教 授, 宮崎元国立箱根療養所泌尿器科医長兼横浜市立大学 医学部講師, 又, 御協力下さつた松尾国立箱根療養所検 查主任, 横浜市立大学医学部第一病理学教室の松下博士 の方々に深甚の謝意を表する).

本論文の要旨は, 昭和 42 年 11 月第 2 回日本パラプレジ 了医学会, 昭和 42 年 12 月第 313 回日本泌尿器科東京地方 会, 昭和 43 年 4 月第 56 回日本泌尿器科学会総会において
発表した。

\section{文献}

1) Abeshouse, B.S. and Tankin, L.H.: J. Urol.: 76, 330, 1956.

2) Aschoff (1928) cited from Goyanna.

3) Allen, T.D. and Henderson, B.W.: J. Urol., 93, 50, 1965.

4) Ball, J.K., Field, W.E.H., Roe, F.J.C. Path, M.C. and Walter, M. J. Urol.: 36, 225, 1964.

5) Blake, J.: Brit. J. Urol., 39, 181, 1967.

6) Connery, D.B.: J. Urol., 69, 121, 1953.

7) Culp, D.A.: J. Urol., 91, 583, 1964.

8) Dimmette, C.R.M., Sproat, M.H.F. and Sayegh, E.S.: J. Urol., 75, 680, 1956.

9) Eisenberg, R.B., Roth, R.B. and Schweinberg, M.H.: J. Urol., 84, 544, 1960.

10) Emmett, J.L. and McDonald, J.R.: J. Urol., 48, 257, 1942.

11) Enderelen (1904) cited from Goyanna.

12) Falk, C.C.: J. Urol., 72, 310, 1954.

13) Formiggini (1920) cited from Rabson.

14) Goebel, C. (1905) cited from Rabson.

15) Goyanna, R. and Emmett, J.L.: J. Urol., 65, 391, 1951.

16) Grieve, J.: Brit. J. Urol., 37, 157, 1965.

17）長谷川 泰：日泌尿会誌, 46, 296, 1955.

18) Hinman, F. and Cordonnier, J.: J. Urol., 34, 302, 1935.

19) Holley, P.S. and Mellinger, G.T.: J. Urol., 86, 235, 1961.

20) 市川篤二, 辻 一郎, 斎藤豊一, 新島端夫 : 日 泌尿会誌，42，190，1951.

21）市川篤二,辻一郎, 石井澄子：日泌尿会誌, 43, 19, 1952.

22) Kittredge, W.E., Collett, A.J. and Morgan, C.: J. Urol., 91, 145, 1964.

23) Laskowski, T.Z. and Scott, F.B.: J. Urol., 94, 549, 1956.

24) McIntosh, J.F. and Scott, F.B., G.: J. Urol., 73, 820, 1955.

25) Melicow, M.M.: J. Urol., 68, 261, 1952.

26) Melzak, J.: Paraplegia, 4, 85, 1966.

27) Mostofi, F.K.: J. Urol., 71, 705, 1954.

28) Nesbit, R.M.: J. Urol., 75, 443, 1956.

29) Nyquist, R.H. and Bors, E.: Paraplegia, 5, $22,1967$.

30) O'Flynn, J.D. and Mullaney, J.: Brit. J. Urol., 34, 461, 196,7.

31) Politano, V.A.: J. Urol., 75, 633, 1956.

32) Pund, E.R., Yount H.A. and Snodgrass, W.T.: J. Urol., 68, 242, 1952.

33) Rabson, S.M.: J. Urol., 35, 312, 1936. 
34) Robbins, S.L.: Pathology, third ed. p. 8182, Saunders Co. Philadelphia, 1967.

35) Roe, F.J.C. and Path, M.C.: Brit. J. Urol., 36, 238, 1964 .

36) Sakkas, J.L.: Inter, Surg., 45, 71, 1966.

37) Salm, R.: Brit. J. Urol., 34, 67, 1967.

38) Sayegh, E.S.: J. Urol., 63, 353, 1950.

39) Schabad, A.L.: Ztsch. Urol., 52, 520, 1959.

40) Scott, W.W.: J. Urol., 65, 235, 1951.

41) Shaw, J.L., Gislason, G.J. and Imbriglia, J.E.: J. Urol., 79, 815, 1958.

42) Simon, W., Cordonnier, J.J. and Snodgrass, W.T.: J. Urol., 88, 797, 1962.

43) Smith, B.A., Webb, E.A. and Price, W.E.:
J. Urol., 87, 279, 1962.

44) Smith, J.C. and Badenoch, A.W.: Brit. J. Urol., 37, 93, 1965.

45) Stirling, C. and Ash, J.E.: J. Urol., 45, 342, 1941.

46) 高崎悦司：日泌尿会誌，48，777，1957.

47) 辻一郎, 黒田恭一, 高瀬吉雄 : 日泌尿会誌, 42, 306, 1951.

48) 辻一郎, 広川浩一, 石井澄子: 日泌尿会誌, 43, 501, 1952.

49) Von Brunn, A. (1893) cited from Nesbit.

50) Wheeler, J.D. and Hill, W.T.: Cancer, 7, 119, 1954.

（1972年 2 月 2 日受付） 